\title{
PENINGKATAN KESELAMATAN DIRI PERAWAT MELALUI OPTIMALISASI FUNGSI MANAJEMEN
}

\author{
Mayanti Mahdarsari ${ }^{*}$, Hanny Handiyani ${ }^{2}$, Hening Pujasari ${ }^{2}$ \\ 1. Fakultas Keperawatan Universitas Syiah Kuala, Darussalam Banda Aceh 23111, Indonesia \\ 2. Fakultas Ilmu Keperawatan Universitas Indonesia, Depok 16424, Indonesia \\ *E-mail: mya_self13@yahoo.com
}

\begin{abstract}
Abstrak
Indikator mutu pelayanan dinilai dari perilaku tenaga kesehatan khususnya perawat dalam menjaga keselamatan dirinya. Budaya organisasi, komunikasi antar perawat, pengendalian, dan hubungan tim serta pelatihan yang kurang dapat memengaruhi perilaku perawat dalam menjaga keselamatan diri. Jika keselamatan dan kesehatan perawat tidak diperhatikan akan terjadi peningkatan absensi, ketidakpuasan bekerja, produktifitas dan konsentrasi perawat dalam bekerja menurun. Penelitian bertujuan mengidentifikasi determinan perilaku perawat dalam menjaga keselamatan dirimenggunakan metode analitik korelatif pada 105 perawat pelaksana di rumah sakit dengan metode accidental sampling. Alat ukur menggunakan kuesioner dan lembar observasi. Data dianalisis menggunakan independent $t$ test dan uji chi-square. Faktor-faktor yang mempengaruhi perilaku perawat dalam menjaga keselamatan diri:budaya organisasi $(\mathrm{p}=0,004 ; \mathrm{CI}=1,831-38,404)$, komunikasi $(\mathrm{p}=0,003 ; \mathrm{CI}=1,776-14,845)$, pengendalian $(\mathrm{p}=0,012 ; \mathrm{CI}=1,457-14,790)$, hubungan tim $(p=0,016 ; C I=1,337-9,035)$, serta pelatihan $(p=0,014 ; C I=1,365-8,924)$. Hasil ini dapat menjadi dasar bagi rumah sakit untuk meningkatkan perilaku perawat menjaga keselamatan diri.
\end{abstract}

Kata kunci: determinan, keselamatan, perawat, perilaku

\begin{abstract}
Improving Nurses Safety through Organization Culture, Communication, Controlling Function, Team Relationships and Training. Indicators of service quality assessed from the behavior of health personnels in maintaining their safety. Organizational culture, communication between nurses, controlling function, team relationshipst hat are less and less training can influence the behavior of nurses in maintaining personal safety. If the safety and health of nurses are not considered to be an increase in attendance, unsatisfactory work, productivity and concentration of nurses in work declined. This study aimed to identify the determinants of nursing behavior in maintaining personal safety by using correlative analytic methods to 105 nurses at hospital with accidental sampling method. Data collected from questionnaires and observation sheets were analyzed using independent $t$ test and chisquare test. Factors that influenced nurses' behavior in maintaining personal safety were organizational culture ( $p=$ 0.004; $C I=1.831-38.404)$, communication $(p=0.003 ; C I=1.776-14,845)$, controlling function $(p=0.012 ; C I=1.457$ 14.790), team relationships ( $p=0.016 ; C I=1.337-9.035)$, and training $(p=0.014 ; C I=1.365-8.924)$. These results can be the basis for hospitals to improve the behavior of the nurses keep personal safety.
\end{abstract}

Keywords: behavior, determinants, nurse, safety

\section{Pendahuluan}

Asuhan keperawatan yang berkualitas yang diberikan oleh perawat perlu dilindungi oleh undang-undang. Undang-Undang RI Nomor 36 tahun 2009 tentang kesehatan, pasal 164 menyebutkan bahwa upaya kesehatan kerja ditujukan untuk melindungi pekerja agar hidup sehat dan terbebas dari gangguan kesehatan. Manyele, Ngonyani, dan Eliakimu (2008) menyatakan pemimpin termasuk pemerintah diwajibkan untuk memberikan informasi kepada karyawan tentang bahaya-bahaya yang ada di tempat kerja serta cara untuk menghindarinya. Salah satu tempat yang memiliki bahaya adalah rumah sakit. 
Banyak perawat yang terpapar bahaya ketika melakukan pekerjaannya. Sebuah penelitian di rumah sakit melaporkan perawat jatuh atau terpeleset karena lantai yang licin 5,9\% (Szeto, Law, Lee, Lau, Ying Chan \& Wai Law, 2010). Angka kejadian akibat paparan bahan kimia ini 0,5-1,9 kasus per 1000 perawat per tahun (Trinkoff, Brown, Caruso, Lipscomb, Johantgen, Nelson, Sattler, \& Selby, 2007). Penelitian di Lusaka menemukan $11,4 \%$ perawat tertular Tuberkulosis (TB) (Menzies, Joshi, \& Pai, 2007). Perawat tertular Human Immunodeficiency Virus/ HIV pada saat bekerja 57\%. Perawat yang mengalami nyeri muskuloskeletal (sakit pada punggung) sebagai dampak dari pekerjaan sebesar 52\%. Pich, Hazelton, Sundin dan Kable (2010) melaporkan perawat mengalami kekerasan baik fisik maupun verbal sebesar $60-90 \%$, tertusuk jarum suntik 52,9\% (Manyele, Ngonyani, \& Eliakimu, 2008).

Bahaya di rumah sakit akan berdampak pada kesehatan, keselamatan perawat, dan selanjutnya pada kualitas pelayanan di rumah sakit. Hal ini perlu mendapat perhatian baik dari perawat maupun rumah sakit. Jika keselamatan dan kesehatan perawat tidak diperhatikan akan terjadi peningkatan absensi, ketidakpuasan bekerja, produktifitas menurun, hilangnya kepercayaan diri, kreatifitas dan konsentrasi perawat dalam bekerja. Mcnamara (2010) menjelaskan konsekuensi negatif dari keadaan kesehatan dan keselamatan perawat yang buruk adalah penurunan pendapatan rumah sakit, absensi, produktivitas berkurang dan kesalahan medis (Palumbo, Mclaughlin, Mcintosh, \& Rambur, 2011).

Menjaga keselamatan dan kesehatan pekerja tidak terlepas dari peran organisasi. Organisasi dapat membentuk perilaku nilai-nilai yang dianut oleh pekerjanya. Nilai inti organisasi akan dipegang teguh dan dianut secara meluas dalam suatu budaya yang kuat. Budaya kuat dapat memengaruhi individu, kinerja dan lingkungan kerja. Organisasi merupakan pengendali dan penentu arah dalam membentuk sikap dan perilaku manusia. Perilaku individu dalam organisasi akan diwarnai oleh budaya organisasi yang dianut (Pramudjono, 2015).

Komunikasi dan hubungan tim juga merupakan salah satu hal penting dalam meningkatkan keselamatan perawat. Komunikasi dan hubungan tim merupakan sebuah proses yang dapat dilaksanakan melalui rapat, pengumpulan informasi, pendapat dalam melaksanakan program kerja, evaluasi program kerja, penyelesaian masalah bersama, bimbingan serta arahan, serta penjelasan yang bermanfaat untuk mengurangi kesenjangan komunikasi antar pimpinan dan sesama staf.

Pelatihan bagi perawat merupakan salah satu kebutuhan yang penting untuk meningkatkan perilaku perawat dalam menjaga keselamatan diri. Pelatihan keselamatan diri secara berkala perlu dilakukan agar pengetahuan perawat berkembang terus-menerus sesuai dengan perkembangan ilmu dan teknologi. Selain itu, dijelaskan oleh Sutrisno (2009) bahwa pelatihan bagi staf diperlukan untuk melengkapi keterampilan yang memadai sehingga staf dapat mengerjakan sesuatu dengan benar dan tepat serta dapat memperkecil kesalahan.

\section{Metode}

Penelitian ini merupakan penelitian kuantitatif dengan pendekatan cross sectional dan menggunakan metode analitik korelatif. Teknik pengambilan sampel dilakukan dengan metode accidental sampling pada 105 perawat pelaksana di ruang rawat inap dewasa.

Instrumen yang digunakan dalam penelitian ini berupa kuesioner untuk mengukur faktor-faktor yang memengaruhi perilaku perawat dalam menjaga keselamatan diri yang dipersepsikan oleh perawat pelaksana. Lembar observasi digunakan untuk menilai perilaku perawat dalam menjaga keselamatan diri. Observasi dibantu oleh wakil kepala ruang sebanyak 10 orang di setiap ruang rawat inap. Sebelum melakukan observasi, observer diberikan penjelasan cara melakukan observasi dan selanjutnya dilaku- 
kan uji inter-rater reliability dengan uji Cohen's Kappa. Observer yang nilai Kappanya $>0,60$ mempunyai kemampuan yang sama dengan peneliti, kategori nilai Kappa baik sama dengan > 0,60 dan sangat baik sama dengan 0,70 (Dharma, 2011).

\section{Hasil}

Penelitian ini menemukan bahwa sebagian besar perawat berjenis kelamin perempuan dengan pendidikan vokasional sebesar $79 \%$, perawat pernah mengikuti pelatihan $76,2 \%$. Rerata umur perawat pelaksana 31,43 tahun dan rata-rata lama kerja 6,43 tahun.

Perilaku perawat dalam menjaga keselamatan diri kurang baik 59\%. Perilaku perawat kurang baik dalam menjaga keselamatan diri dari bahaya fisik $(65,7 \%)$, kimia $(52,4 \%)$, biologik (41\%), ergonomik (41,9\%), psikososial $(62,9 \%)$, dan luka-luka benda tajam $(44,8 \%)$.

Faktor-faktor yang memengaruhi perilaku perawat dalam menjaga keselamatan diri adalah perawat pelaksana memiliki beban kerja yang berat $(88,6 \%)$, memiliki hubungan tim yang baik (69,5\%), kepemimpinan kepala ruang yang efektif (79\%), budaya organisasi yang baik $(81 \%)$, memiliki pengendalian yang baik $(77,1 \%)$, serta memiliki komunikasi yang baik $(71,4 \%)$.

Rata-rata umur perawat pelaksana yang memiliki perilaku kurang baik adalah 31,947 tahun dengan standar deviasi sebesar 5,93 sedangkan perawat pelaksana yang memiliki perilaku baik rerata pada umur 31,37 tahun dengan standar deviasai sebesar 5,76. Tidak ada hubungan antara usia dengan perilaku perawat pelaksana dalam menjaga keselamatan diri.

Rata-rata perawat yang memiliki masa kerja 6,86 tahun memiliki perilaku menjaga keselamatan diri baik sedangkan perawat yang masa kerjanya rerata 6,13 tahun memiliki perilaku dalam menjaga keselamatan diri kurang baik. Tidak ada hubungan yang bermakna antara lama kerja dengan perilaku menjaga keselamatan diri perawat.

Budaya organisasi, komunikasi, pengendalian, hubungan tim, dan pelatihan mempunyai hubungan yang bermakna dengan perilaku perawat dalam menjaga keselamatan diri $(\mathrm{p}=$ 0,$004 ; \quad \mathrm{CI}=1,831-38,404, \quad \mathrm{p}=0,003 ; \mathrm{CI}=$ 1,776-14,845, $\mathrm{p}=0,012 ; \mathrm{CI}=1,457-14,790$, $\mathrm{p}=0,016 ; \mathrm{CI}=1,337-9,035, \mathrm{p}=0,014 ; \mathrm{CI}=$ 1,365-8,924). Budaya organisasi yang kuat akan memengaruhi perilaku perawat yang baik dalam menjaga keselamatan diri sebesar 8,386 kali.

Komunikasi baik mempunyai peluang 5,135 kali lebih besar dalam membentuk perilaku perawat yang baik dalam menjaga keselamatan diri. Pengendalian yang baik akan mempunyai peluang 4,643 kali lebih besar untuk perawat mempunyai perilaku baik dalam menjaga keselamatan diri. Hubungan tim yang baik akan mempunyai peluang 3,475 kali lebih besar untuk perawat mempunyai perilaku baik dalam menjaga keselamatan diri. Pelatihan akan mempunyai peluang sebesar 3,49 kali lebih besar untuk perawat mempunyai perilaku baik dalam menjaga keselamatan diri.

\section{Pembahasan}

Penelitian terkait umur perawat di ruang rawat inap dewasa menunjukkan tidak ada hubungan yang bermakna antara umur dengan perilaku perawat dalam menjaga keselamatan diri. Hal ini dapat disebabkan oleh kebosanan atau kejenuhan perawat yang berdampak pada kemerosostan produktivitas dalam melakukan pekerjaan seiring dengan bertambahnya usia. Robbins (2006) menyatakan bahwa produktivitas dapat merosot dengan makin bertambahnya usia seseorang. Hasil penelitian ini diperkuat oleh hasil penelitian yang dilakukan oleh Yulita (2013) yang menyatakan bahwa tidak ada hubungan yang bermakna $(\mathrm{p}=0,572)$ antara karakteristik usia perawat dengan perilaku perawat dalam menjaga keselamatan perawat terhadap agen biologik. 
Tidak ada hubungan yang bermakna antara masa kerja dengan perilaku perawat dalam menjaga keselamatan diri. Hal ini dapat terjadi akibat masih sedikit perawat yang pernah mengikuti pelatihan tentang keselamatan walaupun rata-rata masa kerja perawat sudah cukup lama 6,15 tahun. Walaupun perawat rata-rata sudah cukup berpengalaman dalam melakukan pekerjaan yaitu sekitar 6,15 tahun namun perawat tetap membutuhkan pelatihan-pelatihan. Robbins (2003) menyatakan keselamatan dapat ditingkatkan dengan pelatihan (Training) dan edukasi kepada perawat. Hasil ini sama dengan hasil penelitian yang dilakukan Dewi (2011) yang menjelaskan bahwa tidak ada hubungan yang bermakna antara masa kerja dengan penerapan keselamatan perawat oleh perawat pelaksana.

Tidak ada hubungan yang bermakna antara tingkat pendidikan dengan perilaku perawat dalam menjaga keselamatan diri. Hal ini dapat disebabkan oleh perawat yang belum pernah mengikuti pelatihan-pelatihan tentang keselamatan. Sulistyani dan Rosidah (2009) menyatakan pendidikan dan pelatihan harus berjalan seiring. Seseorang dengan pendidikan tinggi perlu mendapat pelatihan untuk meningkatkan pengetahuannya tentang keselamatan. Penelitian ini diperkuat Yulita (2013) yang menyatakan bahwa tidak ada hubungan yang bermakna antara tingkat pendidikan dengan perilaku perubahan keselamatan perawat $(\mathrm{p}=0,641)$.

Tidak ada hubungan yang bermakna antara jenis kelamin dengan perilaku perawat dalam menjaga keselamatan diri. Hal ini dapat disebabkan rerata jenis kelamin perawat adalah perempuan dimana perawat perempuan telah berkeluarga dan memiliki anak sehingga kurang fokus dalam melakukan pekerjaannya. Perhatian perawat perempuan akan lebih mudah terbagi antar keluarga dan pekerjaan. Adanya kondisi salah satu anggota keluarga yang sakit dan faktor kelelahan juga akan meningkatkan stres pada perawat yang akan berpengaruh pada perilaku perawat. Almasitoh (2011) menyatakan peran ganda sebagai pe- kerja maupun ibu rumah tangga mengakibatkan tuntutan yang lebih terhadap wanita. Penelitian ini diperkuat Ayu (2011) yang menguatkan bahwa jenis kelamin tidak memiliki hubungan yang bermakna dengan perilaku keselamatan dan kesehatan kerja perawat.

Ada hubungan yang bermakna antara pelatihan dengan perilaku perawat dalam menjaga keselamatan diri. Hal ini dapat dijelaskan bahwa untuk meningkatkan kemampuan perawat dalam menjaga keselamatan diri diperlukan pelatihan. Seluruh perawat perlu mendapatkan pelatihan keselamatan dan penyegaran kembali secara berkala sehingga pengetahuan perawat akan terus berkembang sesuai dengan perkembangan zaman dan teknologi. Pelatihan diperlukan untuk melengkapi karyawan dengan keterampilan yang tepat, cara-cara untuk menggunakan peralatan kerja yang tepat, sehingga karyawan dapat mengerjakan sesuatu dengan benar dan tepat serta dapat memperkecil kesalahan (Sutrisno, 2009). Hasil penelitian ini diperkuat Sahara (2011) yang menyatakan bahwa ada hubungan yang bermakna antara pelatihan dan ketersediaan APD dengan kepatuhan perawat dan bidan dengan kewaspadaan universal $(\mathrm{p}=0,000)$.

Tidak ada hubungan yang bermakna antara beban kerja dengan perilaku perawat dalam menjaga keselamatan diri. Hal ini dapat dikarenakan permasalahan beban kerja perawat selama ini kurang banyak yang memahami terutama pimpinan organisasi tertinggi, sehingga perhitungan beban kerja perawat tidak tepat. Pekerjaan yang dilakukan perawat bermacammacam dan belum jelas wewenang serta tanggung jawabnya. Jumlah tenaga yang kurang dapat menambah beban kerja perawat (Kurniadi, 2013). Hasil penelitian Pekkarinen, et al. (2013) menyatakan bahwa beban kerja fisik yang berat memiliki risiko yang lebih tinggi bagi perawat untuk mengalami gangguan musculoskeletal.

Ada hubungan yang bermakna antara hubungan tim dengan perilaku perawat dalam 
menjaga keselamatan diri. Hal ini dapat terjadi karena tim kerja merupakan kelompok yang upaya-upaya individualnya menghasilkan suatu kinerja yang lebih besar daripada jumlah dari masukan individu-individu. Suatu tim kerja membangkitkan sinergi positif lewat upaya yang terkoordinasi. Hubungan tim kerja yang kuat dan baik akan membentuk hubungan personal dalam lintas fungsi sehingga menjadi efektif dan akan berdampak pada peningkatan kinerja dan perubahan perilaku karyawan (Bhatnagar, 2008 dalam Tarigan, Salim, Troena, \& Setiawan, 2012).

Tidak ada hubungan yang bermakna antara kepemimpinan dengan perilaku perawat dalam menjaga keselamatan diri. Hal ini dapat terjadi karena kepemimpinan bukan satu-satunya faktor yang penting dalam keberhasilan suatu proses. Masih banyak faktor lain yang berkontribusi diantaranya faktor individu, pekerjaan dan organisasi. Selain faktor kepemimpinan faktor lain yang menentukan keberhasilan penerapan budaya keselamatan adalah faktor lingkungan kerja eksternal, struktur dan sistem, pengetahuan dan keterampilan indivi$\mathrm{du}$, lingkungan kerja, kebutuhan dan motivasi (Mulia, 2010). Hasil penelitian tersebut berbeda dengan hasil penelitian Vreis, Bakker, dan Oontenveld (2009) yang menyatakan bahwa kepemimpinan efektif adalah kepemimpinan yang berorientasi pada manusia. Hal ini ditunjukkan dengan adanya hubungan yang bermakna antara kepemimpinan dengan perilaku, komitmen, serta kinerja tim bawahan.

Ada hubungan yang bermakna antara budaya organisasi dengan prilaku perawat dalam menjaga keselamatan diri. Hal ini dapat terjadi karena kekuatan budaya organisasi masih kurang. Belum semua perawat mengetahui dan memahami budaya organisasi yang dianut. Hal ini tentunya akan memengaruhi perilaku perawat. Organisasi yang memiliki budaya organisasi yang kuat akan berpengaruh terhadap perilaku dan sikap anggotanya. Organisasi merupakan pengendali dan arah dalam membentuk sikap dan perilaku manusia. Perilaku individu dalam organisasi akan diwarnai oleh budaya organisasi yang dianut (Pramudjono, 2015). Hasil penelitian ini sama dengan hasil penelitian Burdahat (2009) yang menyatakan bahwa budaya organisasi memengaruhi kinerja perawat pelaksana yang tercermin dalam perilaku perawat dalam melakukan pekerjaan.

Ada hubungan yang bermakna antara pengendalian dengan perilaku perawat dalam menjaga keselamatan diri. Hal ini dapat terjadi karena pengendalian merupakan suatu proses pemantauan tindakan untuk menjamin hasil yang diharapkan. Seorang manajer harus proaktif dalam memperbaiki seluruh pelaksanaan atau kegiatan dalam suatu organisasi. Kegiatan pada fungsi pengendalian bertujuan untuk memastikan bahwa proses pelaksanaan keselamatan perawat telah dilakukan dengan baik dan benar (Marquis \& Huston, 2010; RNAO, 2008). Hasil penelitian oleh Parmin (2009) menyatakan bahwa ada hubungan antara pengawasan dengan motivasi perawat pelaksana $(\mathrm{p}=0,003)$.

Ada hubungan yang bermakna antara komunikasi dengan perilaku perawat dalam menjaga keselamatan diri. Hal ini dapat terjadi karena komunikasi yang baik dapat memengaruhi persepsi seseorang. Penerapan komunikasi yang baik dari atasan ke bawahan dan sebaliknya harus dipertahankan agar tidak ada salah persepsi, sehingga semua pekerjaan dapat berjalan lancar dan segala permasalahan yang terjadi dapat diselesaikan dengan bijaksana. Komunikasi yang baik adalah komunikasi terbuka, dimana hubungan antara dua orang atau lebih untuk menyampaikan atau meneruskan pesan yang berharga bagi organisasi (Kurniadi, 2013). Hasil penelitian ini serupa dengan hasil penelitian Hamdi dan Rajablu (2012) yang menjelaskan bahwa komunikasi antar pemimpin dan antar anggota akan membawa kedekatan yang menyebabkan anggota lebih merasa memiliki organisasi tersebut.

Perilaku perawat dalam menjaga keselamatan diri dari bahaya fisik, kimia dan psikososial 
masih sangat kurang. Apabila perilaku perawat dalam menjaga keselamatan diri dari bahaya fisik, kimia dan psikososial tidak dijaga maka akan berdampak pada risiko cidera pada perawat, angka absensi perawat, produktivitas perawat dalam melakukan pekerjaannya dan banyaknya konflik yang terjadi antar perawat maupun keluarga pasien sehingga meningkatkan stres kerja pada perawat. Semua hal tersebut akan mengakibatkan menurunnya kualitas pelayanan keperawatan pada suatu rumah sakit.

Pendidikan perawat yang masih rendah (perawat vokasional) serta pelatihan yang kurang akan memengaruhi pengetahuan, keterampilan, perilaku, dan tindakan perawat dalam melakukan pekerjaannya.

\section{Kesimpulan}

Gambaran karakteristik perawat dengan pendidikan vokasional, dan sebagaian besar belum pernah mengikuti pelatihan tentang keselamatan diri. Perawat mempunyai perilaku kurang baik dalam menjaga keselamatan diri. Perilaku perawat kurang baik dalam menjaga keselamatan diri dari bahaya fisik adalah $65,7 \%$, kimia 52,4\%, biologik $41 \%$, ergonomik $41,9 \%$, psikososial $62,9 \%$, dan luka-luka benda tajam $44,8 \%$.

Budaya organisasi, komunikasi, pengendalian, hubungan tim, dan pelatihan merupakan variabel yang mempunyai hubungan bermakna dengan perilaku perawat dalam menjaga keselamatan diri. Umur, lama kerja, pendidikan, jenis kelamin, beban kerja, kepemimpinan, dan budaya organisasi merupakan variabel yang tidak mempunyai hubungan bermakna dengan perilaku perawat dalam menjaga keselamatan diri.

Pihak manajemen rumah sakit dapat menggunakan hasil penelitian ini sebagai tolak ukur untuk meningkatkan perilaku perawat dalam menjaga keselamatan diri dan perlu meningkatkan komitmen yang kuat dalam bentuk kebijakan tertulis yang jelas, dan mudah dimengerti serta diketahui oleh seluruh perawat. Pihak rumah sakit juga sebaiknya mengaktifkan K3RS, meningkatkan kinerja Tim PPIRS dengan meningkatkan fungsi manajemen: perencanaan, pengorganisasian, ketenagaan, pengarahan, dan pengawasan. Fasilitas dan peralatan APD perlu disediakan juga penting untuk meningkatkan pelatihan keselamatan diribagi paraperawat. Pihak manajemen rumah sakit perlu menambah orang yang bertugas untuk mendorong/mengantarkan pasien sehingga pekerjaan perawat dapat lebih ringan.

Hasil penelitian ini dapat memberikan masukan bagi perawat pelaksana untuk lebih meningkatkan perilaku dalam menjaga keselamatan diri dari bahaya fisik biologis, kimia, ergonomik, psikososial, dan luka-luka benda tajam. Strategi yang dapat dilakukan adalah dengan mengikuti pelatihan-pelatihan yang dapat meningkatkan pengetahuan dan keterampilan perawat serta lebih patuh terhadap peraturan dan kebijakan terkait keselamatan di rumah sakit (INR, NN, TN).

\section{Referensi}

Almasitoh, U.H. (2011). Stres Kerja Ditinjau dari Konflik Peran Ganda dan Dukungan Sosial pada Perawat. Jurnal Psikologi Islam, 8 (168), 63-82.

Ayu, N.M. (2012). Pengaruh penggunaan buku panduan keselamatan dan kesehatan kerja pada perilaku keselamatan dan kesehatan kerja perawat di RS Siaga Raya (Tesis magister, tidak dipublikasikan). Fakultas Ilmu Keperawatan Universitas Indonesia, Depok, Jawa Barat, Indonesia.

Burdahat. (2009). Hubungan budaya organisasi dengan kinerja perawat pelaksana di RSUD Sumedang Tahun 2009 (Tesis magister, tidak dipublikasikan). Fakultas Ilmu Keperawatan Universitas Indonesia, Depok, Jawa Barat, Indonesia.

Dewi, S.C. (2011). Hubungan fungsi manajemen kepala ruang dan karakteristik perawat 
dengan penerapan keselamatan pasien dan perawat di Irna 1 RSUP Dr. Sardjito Yogyakarta (Tesis magister, tidak dipublikasikan). Fakultas Ilmu Keperawatan Universitas Indonesia, Depok, Jawa Barat, Indonesia.

Dharma, K.K. (2011). Metodologi penelitian keperawatan (pedoman melaksanakan dan menerapkan hasil penelitian). Jakarta: Trans Info Media.

Hamdi, S. \& Rajablu, M. (2012). Effect of supervisor-subordinate communication and leadership style on organizational commitment of nurses in health care setting. International Journal of Business and Management. Diperoleh dari http://www. ccsenet.org/journal/index.php/ijbm/article/vi ew/19723

Kurniadi, A. (2013). Manajemen keperawatan dan perspektifnya: Teori konsep dan aplikasi. Jakarta: FKUI.

Manyele, S.V, Ngonyani, H.A.M, \& Eliakimu, E (2008). The status of occupational safety among health service providers in hospitals in Tanzania. Tanzania Journal of Health Research, 10 (3). Diperoleh dari http://www.bioline.org.br/pdf?th08027

Marquis, B.L., \& Huston, C.J. (2010). Kepemimpinan dan manajemen keperawatan. Jakarta: Penerbit Buku Kedokteran EGC.

Menzies, D., Joshi, R., \& Pai, M. (2007). Risk of tuberculosis infection and disease associated with work in health care settings. International Journal of Tuberculosis and Lung Disease, 11 (6), 593-605.

Mulia, S. (2010). Pengaruh pelatihan keselamatan pasien terhadap pemahaman perawat pelaksana mengenai penerapan keselamatan pasien di RS Tugu Ibu Depok (Tesis magister, tidak dipublikasikan). Fakultas Ilmu Keperawatan Universitas Indonesia, Depok, Jawa Barat, Indonesia.

McNamara, S.A. (2010). Workplace violence and its effects on patient safety: Patient safety first. AORN Journal, 92 (6). Diperoleh dari https://www.ncbi.nlm.nih.gov/pubmed/2113

0206 doi: 10.1016/j.aorn. 2010.07.012

Mulyatiningsih, S. (2013). Determinan perilaku perawat dalam melaksanakan keselamatan pasien di rawat inap RSAU DR. Esnawan Antariksa Jakarta (Tesis magister, tidak dipublikasikan). Fakultas Ilmu Keperawatan Universitas Indonesia, Depok, Jawa Barat, Indonesia.

Palumbo, M.V., Mclaughlin, V., Mcintosh, B., \& Rambur, B. (2011). Practical nurses' health and safety in nursing homes. Nursing Research. Diperoleh dari https://www.ncbi.n lm.nih.gov/pubmed/22359843

Parmin. (2009). Hubungan pelaksanaan fungsi manajemen kepala ruang dengan motivasi perawat pelaksana di ruang rawat inap RSUP Undatu Palu (Tesis magister, tidak dipublikasikan). Fakultas Ilmu Keperawatan Universitas Indonesia, Depok, Jawa Barat, Indonesia.

Pekkarinen, L., Elovainio, M., Sinervo, T., Heponiemi, T., Aalto, A., Noro, A., \& HaSoveri, H. (2013). Job demands and musculoskeletal symptoms among female geriatric nurses: the moderating role of psychosocial resources. American psychological association. Diperoleh dari http://psycnet.apa.org/psycinfo/2013-06790001/ doi: http://dx.doi.org/10.1037/a003 1801

Pich, J, Hazelton, M, Sundin, D \& Kable, A. (2010). Patient-related violence against emergency department nurses. Nursing and Health Sciences journal. Diperoleh dari http://onlinelibrary.wiley.com/doi/10.1111/j. 1442-2018.2010.00525.x/abstract

Pramudjono, P. (2015). The Influences of Organizational Culture, Moral Hierarchy Level, and Motivation towards the Teacher's Commitment. American Journal of Educational Research, 3 (1), 20-24. http://doi.org/10.12691/education-3-1-5

Registered Nurses' Association of Ontario (RNAO). (2008). Healthy work environment best practice guidelines: workplace health, 
safety and well-being for the nurse. Ontario. Diperoleh dari http://www.rnao.org/projects/ hwe.asp/.

Sahara, A. (2011). Faktor-faktor yang berhubungan dengan kepatuhan perawat dalam dan bidan dalam melaksanakan kewaspadaan universal di RS Palang Merah Indonesia (Skripsi, tidak dipublikasikan). Fakultas Ilmu Keperawatan Universitas Indonesia, Depok, Jawa Barat, Indonesia.

Sutrisno, E. (2009). Manajemen sumber daya manusia. Jakarta: Kencana.

Szeto, G,. Law, K.Y, Lee, E., Lau, T., Chan, S.Y., \& Wai, S.W. (2010). Multifaceted ergonomic intervention programme for community nurses: pilot study. Journal of advanced nursing, 66 (5), 1022-1034. doi: 10. 1111/j.1365-2648.2009.05255.x.

Tarigan, H., Salim, U., Troena, E.A., \& Setiawan, M. (2012). Pengetahuan individu dan pengembangan kerja tim berpengaruh terhadap kinerja perusahaan di kawasan industri mm 2100 Cikarang, Bekasi. Jurnal manajemen kewirausahaan. Diperoleh dari http://jurnalmanajemen.petra.ac.id/index.php /man/article/view/18370
Trinkoff, A.M., et. al. (2007). Personal safety for nurses: Chapter 39. Diperoleh dari www.ahr q.gov/nurses/TrinkoffA_PSN.pdf

Vries, R., Bakker, A., Oostenveld, W. (2010). Leadership Communication? The Relations of Leaders'Communication Styles with Leadership Styles, Knowledge Sharing and Leadership Outcomes. Journal of Business and Psychology. Diperoleh dari http:// link.springer.com/article/10.1007/s10869009-9140-2

Yulita, Y. (2013). Pengaruh supervisi refektif interaktif terhadap perilaku keselamatan perawat pada bahaya agen biologik di RSUD Provinsi Kepulauan Riau Tanjung Uban (Tesis, tidak dipublikasikan). Fakultas Ilmu Keperawatan Universitas Indonesia, Depok, Jawa Barat, Indonesia. 